GadjahMadaInternational Journal of Business

January-April2010,Vol.12,No.1,pp.31-54

\title{
THE IMPORTANCE AND USEFULNESS OF CORPORATE ANNUAL REPORTS IN MALAYSIA
}

\author{
Nazli Anum Mohd. Ghazali \\ Department of Accounting, International Islamic University Malaysia
}

The purpose of this study is to examine the perceived importance and usefulness of corporate annual reports in Malaysia and to determine if there is a difference between the perceptions of preparers and users of corporate annual reports. Data for this study were collected using a questionnaire survey conducted in late 2006 and early 2007. Preparers are represented by chief financial officers while users by investment analysts. The mean scores for preparers and users are compared using the independent samples $t$ test and the non-parametric Mann-Whitney test to determine if there are any statistically significant differences in their opinions. The findings reveal that preparers rank the annual report as the most important source of corporate information. Users, on the other hand, rank the annual report as the second most important after the visits to companies. However, the difference in the mean scores of preparers and those of users on the importance of annual reports is not significant at 5 percent level. The difference in the mean scores for the visits to companies is, on the other hand, statistically significant at 5 percent level. An implication for this finding is whether the annual report serves the information needs of analysts for decision-making purposes. An opportunity thus arises for future research to examine information needs of analysts and if there is a gap between information provided in annual reports and that required by analysts.

Keywords: corporate annual reports; disclosure; Malaysia; transparency 
Gadjah Mada InternationalJournal of Business, January-April 2010, Vol. 12,No. 1

\section{Introduction}

The use and importance of corporate annual reports have been the subject of debate for a number of years. Studies in this area have included the characteristics of companies which provide the most useful information (Cerf 1961), whether annual reports are designed to serve users' or reporting preparers' interests (Parker 1982), whether shareholders use annual reports (Hines 1982) and reasons for non-disclosure in annual reports (Chandra and Greenball 1977; McKinnon 1984 and Gray et al. 1990). Among the rationales for non-disclosure are the costs of collecting and preparing data and the cost of competitive disadvantage (Gray et al. 1990). Users and preparers are found to have differing opinions on the cost and value of certain information disclosure (Chandra 1974; and McKinnon 1984). Investors are also reported to find financial statements to be of minor importance to their investment decisions (Baker and Haslem 1973).

For annual reports to be important and useful to users, they must satisfy the information requirements of users, besides being timely and up to date. Annual reports have been reported to be inadequate, hence investors tend to resort to other sources for corporate information (Chandra 1974). Inadequate disclosure has resulted in an information gap between stakeholders' expectations and disclosure provided in annual reports (Hooks et al. (2002). In the Malaysian context, research on the importance of annual reports dates back to 1980 s and 1990s. Ahmad (1988) examined the perceptions of investment analysts on the importance of annual reports in Malaysia while Christopher and Hassan (1999) examined the usefulness of statement of cash flows in Malaysia. Studies by Rahman $(1999,2001)$ looked at the importance of annual reports from the perspectives of analysts and accountants, respectively, in Malaysia. None of the studies conducted in Malaysia has investigated as to whether there is a difference in the perceptions of users and preparers on the importance and usefulness of corporate annual reports in Malaysia.

The usefulness of corporate annual reports partly depends on the information disclosed in the annual reports. The level of disclosure to a certain extent is influenced by cultural and business environments of that particular country. Malaysia's business environment has been categorized as highly concentrated with the largest shareholder group being nominee companies. ${ }^{1}$ According to Capulong et al. (2000), the majority of nominees are owned by families. Additionally, Claessens et al. (2000) report that at the 20 percent cut-off level, 67.2 per-

\footnotetext{
${ }^{1}$ Source: Social and Structural Review Update: Malaysia (2001), published by the World Bank Group, reported that in more than half of the publicly listed companies, the five largest shareholders owned 60 percent or more of the companies' equity.
} 
Ghazali-TheImportanceand UsefulnessofCorporate AnnualReportsin Malaysia

cent of Malaysian publicly listed companies are in the hands of families, and 85 percent have owner managers. The prevalence of family businesses and owner-managed companies appears to suggest that information disclosure may be at the minimum level since owners and managers are closely involved and informed about the business activities.

Minimal disclosure suggests that companies would only disclose information required by the regulatory authorities. Beyond that, private disclosure may be the method for analysts and investors to get additional, relevant and timely information from companies. The importance of private communications is evident in Barker (1998) where analysts interviewed direct contacts from a company, and analysts' meetings are the second most important source of information. It is argued in this paper that because of the nature of the majority of corporations in Malaysia which is essentially built on family businesses, the users of company information may prefer private disclosure to public disclosure such as that in annual reports. The objective of this research is therefore to examine the perceived importance and usefulness of corporate annual reports in Malaysia, and to determine if there are differences in perceptions between preparers and users of annual reports.

This study differs from prior studies on corporate annual reports for a number of reasons. Firstly, changes have taken place in the regulatory framework for financial reporting in Malaysia in the last ten years. Efforts from the regulatory bodies to enhance corporate accountability and transparency are expected to further improve the credibility of annual reports and accordingly the usefulness and importance of annual reports in the decisionmaking process. Secondly, examining users' and preparers' perceptions on annual reports may reveal differences or an information gap that will be relevant for regulators to consider future revisions on accounting standards. The research questions (RQs) of this study are as follows:

RQ1: How do preparers and users view the importance of the various sources of corporate information in Malaysia?

RQ2: How do preparers and users view the uses and importance of corporate annual reports in Malaysia?

RQ3: How do preparers and users view current disclosure practices in Malaysian corporate annual reports?

RQ4: Is there a significant difference between the perception of preparers and that of users on the uses and importance of, and (voluntary) disclosure practices in Malaysian corporate annual reports?

The remainder of the paper is organized as follows. The next section discusses the regulatory framework for financial reporting in Malaysia. This is then followed by a review of prior 
research on corporate annual reports. The ensuing section explains sample selection and data collection procedures. Findings and analysis are presented next. Finally, conclusion and suggestions for future research are provided in the last section.

\section{The Regulatory Framework for Financial Reporting in Malaysia}

The legal and regulatory frameworks for financial reporting in Malaysia are governed by the Companies Act (CA) 1965, accounting standards issued by the Malaysian Accounting Standards Board (MASB) and the Bursa Malaysia (formerly known as the Kuala Lumpur Stock Exchange) Listing Requirements. The accounting profession (the Malaysian Institute of Accountants and the Malaysian Institute of Certified Public Accountants) plays an important role in ensuring that their members follow the code of professional conduct in the preparation of financial statements.

The CA 1965 requires published accounts to present a 'true and fair' view; however, no definition is provided for this term. Section 166A (6) states that whenever any conflict or inconsistency arises between provisions in an applicable approved accounting standard (standards issued by the MASB) and those in the Ninth Schedule of CA in their respective applications to the accounts, the provisions of the approved accounting standard prevail. ${ }^{2}$

The Malaysian Accounting Standards Board (MASB) was formed in 1997 to issue legally binding accounting standards. When the MASB assumed the role of the sole standard setter in Malaysia, it adopted 24 out of the 32 accounting standards issued by the two professional accounting bodies. The MASB then embarked on its program to review and issue its own accounting standards. Standards issued by the MASB were initially referred to as MASB Standards. However, from January 2006 on, to be in line with the International Accounting Standards Board (IASB) convergence program, the MASB has been adopting the standards issued by the IASB and renumbering its accounting standards to correspond with the numbers of the relevant IAS standards issued by the MASB. The standards were renamed Financial Reporting Standards.

The Bursa Malaysia (BM), established in 1973, is a self-regulatory organisation that governs the conduct of its members and member stockbroking companies in securities dealing. Companies listed on the BM are also required to abide by the BM Listing Requirements in addition to approved accounting standards issued by the MASB. The revised Listing Requirements, announced in January 2001, make it mandatory for all public listed

\footnotetext{
${ }^{2}$ This requirement is also stated in paragraph 9.26 of the KLSE Listing Requirements (KLSE 2001).

34
} 
Ghazali-TheImportanceand UsefulnessofCorporate AnnualReportsin Malaysia

companies to disclose in their annual reports among others the particulars of directors and the future prospects of the companies. This information is to be disclosed for annual reports issued on or after 1 June 2001. Directors of public listed companies are also required to undergo continuous training programs conducted by the $\mathrm{BM}$ to equip directors to effectively discharge their duties as directors. This requirement came into effect on 15 February 2001.

In addition, listed companies with financial years ending after 30 June 2001 must disclose in their annual reports the Statement of Corporate Governance stating how they have applied the principles set out in Part 1 of the Malaysian Code of Corporate Governance (MCCG) and the extent to which they have complied with the best practices set out in Part 2 of the MCCG. The MCCG was released in 2000 as part of the efforts to enhance corporate accountability and transparency. The MCCG is one of the initiatives undertaken by the government to regain investors' confidence in the Malaysian market.

The Statement on Internal Control is a mandatory disclosure in annual reports of companies with financial years ending after 31 December 2001. The mandatory disclosures of the Statement of Corporate Governance and the Statement on Internal Control in annual reports of companies are expected to encourage companies to be more transparent in other areas of disclosure.

Listed companies were to ensure that their Boards of Directors comprised at least two or one-third of (whichever was the higher) independent non-executives by 31 July 2001 (KLSE 2001). It may be expected that companies adopting best practices recommended in Part 2 of the MCCG provide more information in their annual reports. That is because independent directors are supposed to carry a monitoring role, protecting the interest of minority shareholders. Additionally, the BM requirement on independent directors, which came into effect on 31 July 2001, could also put pressure on independent directors to show that they are carrying out their perceived monitoring role.

The reviews undertaken by the MASB are aimed at finding the best guides to preparing informative financial reports so that corporations could report their 'financial health' as objectively as possible, and users can make comparisons among company annual reports. The revised listing requirements by the BM are part of the regulatory efforts initiated after the 1997 Asian financial crisis to enhance corporate accountability and transparency. However, whether financial reports, which are prepared according to regulatory guidelines, are useful for users in their decision-making processes remains an elusive issue. 


\section{Prior Literature}

The usefulness and importance of annual reports for investment decisions have been documented in the literature. In a study by Anderson (1981) using postal questionnaires, Australian institutional investors are found to rank the annual report as the most important source of information for investment decisions. Similarly, in another study by Chang et al. (1983) on the perceptions of three groups of investors in the U.S., U.K., and New Zealand, individual investors, institutional investors and financial analysts are also reported to regard the annual report as an important source of information for investment decisions. On the other hand, Eccles and Mavrinac (1995) who surveyed corporate managers, financial analysts and portfolio managers in the U.S. find that the three groups are of the opinion that the annual report comes third behind individual meetings and press releases as the most important medium of corporate communications. The study also reports that respondents consider annual reports to be important to reflect short-term performance but less useful to be a long-term economic value indicator. Additionally, Rogers and Grant (1997) in their study on analysts' reports of 187 large U.S. companies find that almost three-quarters of the information cited by analysts could not be found in annual reports. This finding suggests that even if the annual report is considered themost important source of corporate information and applied during the investment analysis stage, its usefulness in the final decision making may be limited. Additionally, the finding may also imply that the importance of annual reports in developed countries have somewhat declined probably and partly due to the availability of corporate information through other channels which are more timely and up to date.

The relative importance of annual reports can be expected to be negatively related to the availability of other competing information, and such competing sources may be limited in a developing country. That would suggest that the annual report, as a source of information for investment decisions, may assume a more important role in a developing than in a developed country. Previous studies that investigated users' perceptions on annual reports in developing countries generally support the view that users regard the annual report as an important source of information. Corporate annual reports are found to be the most importance source of information by investment analysts in Netherlands (Vergoossen 1993) and Hong Kong (Ho and Wong 2004), by four usergroups $^{3}$ in Jordan (Abu-Nassar and

\footnotetext{
${ }^{3}$ The four user groups are individual shareholders, institutional shareholders, stockbrokers and academics. Bank loan officers rate the annual report third behind visits to companies, communications with management, and discussion with colleagues.
} 
Ghazali-TheImportanceand UsefulnessofCorporate AnnualReportsin Malaysia

Rutherford 1996), by five user-groups ${ }^{4}$ in Saudi Arabia (Naser and Nuseibeh 2003), by eight user-groups 5 in Kuwait (Naser et al. 2003), and by seven usergroups $^{6}$ in Iran (Mirshekary and Saudagaran 2005). However, users in Jordan feel that annual reports are lacking in consistency and comparability(Abu-Nassar and Rutherford 1996). In a more recent study in South Africa, Stainbank and Peebles (2006) find that users regard company reports as the second important after the communications with management.

With regard to items least important, consistent with the findings in Jordan (Abu-Nassar and Rutherford 1996), users in Iran regard tips and rumours, stockbrokers' advice and the advice of friends and acquaintances as least important sources of information (Mirshekary and Saudagaran 2005). This finding is almost similar to Naser et al. (2003) where market rumours, friends' advice and newspapers and magazines are regarded as the least important media by the users of corporate information in Kuwait.

In a study by Ho and Wong (2001), finance directors of listed companies in Hong Kong rank the financial statements in an annual report as the most important type of corporate communications while other information in an- nual reports is ranked the second most important medium. Financial analysts also rank the financial statements in an annual report as the most important source of information while other information in annual reports is ranked the third most important behind company visits and the communications with management. The users and preparers are of similar opinion on discussion with colleagues, computer networks and company handbooks being the least important information sources. These studies show that within developing countries, users regard the annual report as the most important source of information probably because it is one of the few available and credible items of public information prepared within a regulatory framework.

In the Malaysian context, three prior studies document inconsistent results. While Ahmad (1988) reports that investment analysts rank company annual reports as the most important source of information, Rahman (1999) finds that financial analysts view the visits to companies as the most important. Annual reports are ranked the sixth important by financial analysts in Rahman (1999). In a later study by Rahman (2001), accountants in Malaysia rank the annual report as the second important source of informa-

\footnotetext{
${ }^{4}$ The five groups are individual investors, institutional investors, financial analysts, bank credit officers and government representatives.

5 The eight user-groups are institutional investors, individual investors, bank loan officers, government officials, financial analysts, academics, auditors and stock market brokers.

${ }^{6}$ The seven user-groups are bank loan officers, bank investment officers, auditors, tax officers, stockbrokers, institutional investors and academics
} 
tion behind advisory services. With regard to items least important, Ahmad (1988) reports newspapers and magazines and tips and rumours. This finding is substantiated by Rahman $(1999,2001)$ who find newspapers, proxy statements and tips and rumours to be the least important sources of information.

On the use of different sections in annual reports, Ho and Wong (2001) find the income statement, balance sheet and cash flow statement to be the most read items by analysts in Hong Kong. However, the preparers in Hong Kong prefer the notes-to-the accounts to the cash flow statement as one of the three most read sections in the annual report. Meanwhile, Mirshekary and Saudagaran (2005) report that the users of annual reports in Iran rank the profit and loss account followed by the auditors' report and the balance sheet as the most important sections in an annual report. A similar result is also documented in Al-Razeen and Karbhari (2007) where in Saudi, five user groups rank the income statement, the balance sheet and the auditors' report as the most important sections of an annual report. Likewise, in Malaysia the profit and loss account, the balance sheet and the notes-to-the accounts are reported as the three most important parts of an annual report (Ahmad 1988; Rahman 1999, 2001).

The three items least read in the annual reports by analysts are CEO message, directors and senior man- agement profiles and accounting policies (Ho and Wong 2001). The preparers, on the other hand, rate the auditors' report instead of the CEO message as one of the three least read items in the annual reports. Mirshekary and Saudagaran (2005) also document quite similar findings where accounting policies, directors' report and summary and historical information are found to be the least important sections in annual reports by users in Iran. Users in Saudi Arabia rank the board of directors' report ${ }^{7}$ last as compared to the other six sections in an annual report(Al-Razeen and Karbhari2007). In Malaysia, the least important sections in annual reports are the auditors' report, the profiles of board of directors and the profiles of senior management (Ahmad 1988). Rahman (1999), however, provides evidence that the chairman's statement, directors' report and auditors' report to be the least important sections while Rahman(2001) finds the chairman's statement, the profiles of board of directors and pictorial statements to be the least important sections.

On the usefulness of information contained in annual reports, Naser et al. (2003) find that the most important use is to help investors make informed investment decisions followed by to help investors evaluate a company's performance over time and to help investors make a comparison between a company's performance with that of

\footnotetext{
${ }^{7}$ However the mean score of this item is quite high at 3.98 out of a maximum score of 5 .
} 
Ghazali-TheImportanceand UsefulnessofCorporate Annual Reportsin Malaysia

others. Meanwhile, Rahman (1999, 2001) reports that financial analysts and accountants in Malaysia view that the uses of annual reports are to make decisions on behalf of clients/employers, advise clients, and buy, hold and sell shares in a private capacity.

On the issue of adequacy of information disclosed in corporate annual reports, Eccles and Mavrinac (1995) report that users do not see the need for more financial reporting regulations; rather, companies should provide nonfinancial information voluntarily. The perceptions of preparers and users on this issue may differ as shown in Ho and Wong (2001) where CFOs are of the opinion that disclosures in Hong Kong need slight improvement while analysts are of the view that a greater improvement is required. The study also reports that preparers and users have differing opinions on the significance of corporate governance factors in influencing disclosure. Although analysts regard corporate governance as an influencing factor, preparers are of the opposite view, and the difference in opinions is statistically significant at 5 percent level.

The review of prior literature reveals that studies have been carried out in both developed and developing countries. However, in the context of Malaysia, the latest study examining the importance of corporate annual reports was published in 2001. As explained in Section 2 above, a number of guidelines have been implemented after the 1997 Asian financial crisis to restore investors' confidence in the Malaysian market. The reviews undertaken by the MASB, the revised listing requirements by the $\mathrm{BM}$ and the introduction of the MCCG were all aimed at enhancing corporate accountability in Malaysia. In this respect, the present study extends prior research in corporate annual reports by examining the perceptions of preparers and users in a period after the regulatory changes have taken place.

\section{Research Design}

Data for this study were collected using a questionnaire survey conducted in late 2006 and early 2007 . In developing the questionnaire, reference was made to prior studies on corporate annual reports (e.g., Abu-Nassar and Rutherford 1996; Ho and Wong 2001; Naser et al. 2002; and Mirshekary and Saudagaran 2005). The questionnaire was pilot-tested to an accountant and a banker to ensure that the questions were clear, as specific as possible and met the objectives of the research. In this study, preparers are represented by chieffinancial officers (CFOs) while users are represented by investment analysts. The selection of investment analyst can be justified on the basis that investment analysts refer to annual reports in their day-to-day decisionmaking activities. Other users such as creditors, bankers, institutional investors and academics arguably do not refer to annual reports as often as do investment analysts. 
At the time when the questionnaires were to be administered, there were 34 securities firms registered with BM. A cover letter explaining the purpose of the survey together with two sets of questionnaires were sent to the Human Resources Manager of each firm, requesting him or her to identify two senior analysts to fill up the questionnaires. To be comparable with the number of questionnaires (68) sent to investment analysts, 70 sets of questionnaires were sent to CFOs of publicly listed companies. The 70 CFOs were selected using the stratified random sampling from the list of companies listed on the first board of BM.

The questionnaire comprised two parts. The first part sought opinions on various issues relating to corporate annual reports, and the second part sought demographic information. In the first part of the questionnaire, respondents were asked to give their opinions on a scale of " $1=$ not important at all" to " $5=$ very important." The questionnaires were mailed in November 2006. The response rates of the questionnaires are summarized in Table 1.

As can be seen in Table 1, the first request resulted in 25 responses (13 from CFOs and 12 from analysts). In December 2006, reminders were sent requesting those who had not responded to reply as soon as possible. The reminders managed to get 9 (4 from CFOs and 5 from analysts) more responses. The total number of usable replies was 34 . The overall response rate was 27.6 percent. $^{8}$

In comparison to prior studies, the response rate obtained in the present study is acceptable. In terms of the number of responses, Christopher and Hassan (1999) obtained 26 out of 60 (43.3\%), Rahman (2001) obtained 55 out 150 (37\%), while Stainbank and Peebles (2006) obtained 50 out of 172 (29\%). These studies used means and percentages to report and interpret their findings.

Due to the low response rate, a non-response bias test was carried out to determine whether the opinions of non-respondents were significantly dif-

Table 1. Survey Groups and Response rates

\begin{tabular}{|c|c|c|c|c|c|c|}
\hline $\begin{array}{l}\text { Survey } \\
\text { group }\end{array}$ & $\begin{array}{c}\text { Number } \\
\text { surveyed } \\
\text { a }\end{array}$ & $\begin{array}{c}\text { Returned } \\
\text { to sender } \\
\text { b }\end{array}$ & $\begin{array}{c}\text { Usable } \\
\text { response } \\
\text { c }\end{array}$ & $\begin{array}{l}\text { Response } \\
\text { after } \\
\text { reminder } \\
\text { d }\end{array}$ & $\begin{array}{c}\text { Total } \\
\text { usable } \\
\text { response } \\
\mathrm{e}=\mathrm{c}+\mathrm{d}\end{array}$ & $\begin{array}{c}\text { Response } \\
\text { rate } \\
e /(\mathbf{a}-\mathbf{b})\end{array}$ \\
\hline CFOs & 70 & 8 & 13 & 4 & 17 & $27.42 \%$ \\
\hline Analysts & 68 & 7 & 12 & 5 & 17 & $27.87 \%$ \\
\hline
\end{tabular}

${ }^{8}$ This is calculated as 34 (number of responses) divided by number of questionnaires sent out excluding returned-to-sender $(70+68-8-7=123) .34 / 123=27.6$ percent. 
Ghazali-TheImportanceandUsefulness ofCorporateAnnualReportsin Malaysia

ferent from those of respondents. If the views of the two groups were significantly different, the validity of the results might be questionable. Oppenheim (1992) suggests that if the late respondents are assumed to represent non-respondents, it is possible to detect the non-response bias in the sample. To test for the non-response bias, a Mann-Whitney test was performed comparing the opinions of the 9 late respondents (those who responded after the reminders) to 9 responses randomly selected from those responded before the reminders (early respondents). The results showed that there was no significant difference between the two groups. Thus, it could be concluded that the non-response bias was not present in the data.

The questionnaire seeks for information on ages, genders and working experiences of the respondents. Table 2 shows that almost 80 percent of the respondents are over 30 years of age with about half of the respondents in each group of at least 40 years of age. As shown in Table 3, the sample is predominantly male, with only 20.6 percent of the total respondents being female. In terms of working experience, it appears that preparers are more experienced with all the preparers surveyed working for more than 5 years, whereas 5 users have less than 5 years of working experience.

Table 2. Age of Respondents

\begin{tabular}{|c|c|c|c|c|c|c|}
\hline & \multicolumn{2}{|c|}{ Total } & \multicolumn{2}{|c|}{ Preparers } & \multicolumn{2}{|c|}{ Users } \\
\hline & No & $\%$ & No & $\%$ & No & $\%$ \\
\hline $25-30$ & 7 & 20.59 & 1 & 5.88 & 6 & 35.29 \\
\hline $31-35$ & 5 & 14.71 & 3 & 17.65 & 2 & 11.76 \\
\hline $36-40$ & 5 & 14.71 & 4 & 23.53 & 1 & 5.88 \\
\hline $41-45$ & 6 & 17.65 & 3 & 17.65 & 3 & 17.65 \\
\hline $45-50$ & 7 & 20.59 & 3 & 17.65 & 4 & 23.53 \\
\hline Over 50 & 4 & 11.76 & 3 & 17.65 & 1 & 5.88 \\
\hline Total & 34 & 100.00 & 17 & 100.00 & 17 & 100.00 \\
\hline
\end{tabular}

Table 3. Gender of Respondents

\begin{tabular}{|c|c|c|c|c|c|c|}
\hline & \multicolumn{2}{|c|}{ Total } & \multicolumn{2}{|c|}{ Preparers } & \multicolumn{2}{|c|}{ Users } \\
\hline & No & $\%$ & No & $\%$ & No & $\%$ \\
\hline Male & 27 & 79.41 & 12 & 70.59 & 15 & 88.24 \\
\hline Female & 7 & 20.59 & 5 & 29.41 & 2 & 11.76 \\
\hline Total & 34 & 100.00 & 17 & 100.00 & 17 & 100.00 \\
\hline
\end{tabular}


Gadjah Mada InternationalJournal of Business, January-April 2010,Vol. 12,No. 1

Table 4. Working Experience of Respondents

\begin{tabular}{|c|c|c|c|c|c|c|}
\hline & \multicolumn{2}{|c|}{ Total } & \multicolumn{2}{|c|}{ Preparers } & \multicolumn{2}{|c|}{ Users } \\
\hline & No & $\%$ & No & $\%$ & No & $\%$ \\
\hline Less than 5 years & 5 & 14.71 & 0 & 0.00 & 5 & 29.41 \\
\hline $5-10$ years & 7 & 20.59 & 4 & 23.53 & 3 & 17.65 \\
\hline $11-15$ years & 3 & 8.82 & 2 & 11.76 & 1 & 5.88 \\
\hline $16-20$ years & 9 & 26.47 & 6 & 35.29 & 3 & 17.65 \\
\hline $20-30$ years & 10 & 29.41 & 5 & 29.41 & 5 & 29.41 \\
\hline More than 30 years & 0 & 0.00 & 0 & 0.00 & 0 & 0.00 \\
\hline Total & 34 & 100.00 & 17 & 100.00 & 17 & 100.00 \\
\hline
\end{tabular}

\section{Findings and Analysis}

The findings are reported under the following headings:

- Corporate communications, importance and usefulness

- Corporate disclosure

Consistent with prior studies (e.g., Rahman 2001; Ho and Wong 2004; Stainbank and Peebles 2006), mean scores are computed for each item asked in the questionnaire to arrive at an average view. The mean scores for preparers and users are then compared using the independent samples $\mathrm{t}$ test and the non-parametric MannWhitney test to determine if there are any statistically significant differences in their opinions.

\section{Corporate Communications, Importance and Usefulness}

A company can communicate with its stakeholders through a number of sources, including communications through corporate annual reports, websites, newspapers and private meetings. Preparers and users are asked to rate the perceived importance of 10 different sources of corporate information.

\section{Corporate Communications}

Table 5 shows that preparers rank the annual report as the most important source of corporate information (mean= 4.44), followed by Bursa Malaysia information systems (mean=4.35), and other company publications and newsletters (mean $=3.59$ ). However, users take a slightly different view with the visits to company and communications with management are ranked as the most important (mean=4.29), followed by annual reports (mean $=4.18$ ) and Bursa Malaysia information systems (mean= 3.94).

The findings regarding preparers areconsistent with Ho and Wong (2001). However, the finding that users rank the visits to companies as the most important is inconsistent with Ho and Wong (2001) where analysts in Hong Kong perceive financial statements in 


\section{Ghazali-TheImportanceand UsefulnessofCorporate AnnualReportsin Malaysia}

an annual report as the most important while the visits to companies the second important. The present result is also inconsistent with Abu-Nassar and Rutherford (1996), Naser et al. (2003), Naser and Nuseibeh (2003) and Mirshekary and Saudagaran (2005) where users are found to rank company annual reports as the most important source of corporate information. In comparison to previous Malaysian studies, the finding on users is inconsis- tent with Ahmad (1988) and Rahman (2001), but consistent with Rahman (1999).

The high importance placed by users in this study on the visits to companies could be due to the fact that the users need timely and up-to-date information for decision-making purposes. Perhaps this is an indication that private meetings are becoming a more important source of corporate information in Malaysia. It may also imply

Table 5. Perceived Importance of Different Types of Corporate Information Sources

\begin{tabular}{|c|c|c|c|c|c|c|c|}
\hline & To & & Prep & rers & Use & & Sig. \\
\hline & Mean & Rank & Mean & Rank & Mean & Rank & level \\
\hline Annual Reports & 4.18 & 1 & 4.44 & 1 & 4.18 & 2 & .466 \\
\hline $\begin{array}{l}\text { Visits to company and } \\
\text { communication with } \\
\text { management }\end{array}$ & 3.79 & 3 & 3.29 & 6 & 4.29 & 1 & $.028 *$ \\
\hline $\begin{array}{l}\text { Other company } \\
\text { publications } \\
\text { (e.g. prospectuses \& } \\
\text { newsletters) }\end{array}$ & 3.65 & 4 & 3.59 & 3 & 3.71 & 4 & .747 \\
\hline Newspapers & 3.35 & 5 & 3.41 & 4 & 3.29 & 7 & .715 \\
\hline Magazines and journals & 3.33 & 6 & 3.35 & 5 & 3.31 & 6 & .916 \\
\hline $\begin{array}{l}\text { Bursa Malaysia } \\
\text { information system }\end{array}$ & 4.15 & 2 & 4.35 & 2 & 3.94 & 3 & .215 \\
\hline Tips and rumours & 2.29 & 9 & 1.82 & 10 & 2.76 & 10 & $.008 * *$ \\
\hline Stockbrokers' advice & 3.06 & 8 & 3.06 & 7 & 3.06 & 8 & 1.00 \\
\hline $\begin{array}{l}\text { Advice of friends and } \\
\text { acquaintances }\end{array}$ & 2.29 & 9 & 2.12 & 9 & 2.47 & 9 & .280 \\
\hline $\begin{array}{l}\text { Computer networks and } \\
\text { on-line databases }\end{array}$ & 3.21 & 7 & 3.00 & 8 & 3.41 & 5 & .292 \\
\hline
\end{tabular}

* significant at 5\% level; ** significant at $1 \%$ level

$(1=$ not important at all; $5=$ very important $)$ 
Gadjah Mada InternationalJournal of Business, January-April 2010, Vol. 12,No. 1

that in a relationship-based economy, which is usually the case in developing countries, contacts and networking are essential to ensure continued access to corporate information.

With respect to items least important, both preparers and users are in agreement that tips and rumours, and advice of friends and acquaintances are the two least important sources of corporate information. These findings are generally consistent with prior studies (Ahmad 1988; Abu-Nassar and Rutherford 1996; Rahman 1999, 2001; Naser et al. 2003; Mirshekary and Saudagaran 2005).

The independent samples t test is carried out to see whether the mean scores of perceptions between preparers and users on each of the 10 items of corporate information sources are significantly different. As shown in Table 5, the mean scores for tips and rumours are significantly different at 1 percent level whereas those for the visits to companies are significant at 5 percent level. Due to the small sample size and ordinal data, a non-parametric alternative, Mann-Whitney test, are also carried out. The results are consistent with the t tests, showing that tips and the visits to companies are significant at 1 percent and 5 percent levels, respectively. These results imply that apart from these two sources, there are no significant statistical differences in the perceptions of preparers and users on the importance of the other eight information sources.

\section{Perceived Importance of Different} Sections of Annual Reports

Preparers and users are also asked about the importance of the different sections of annual reports. It can be seen in Table 6 that both preparers and users rank the income statement and cash flow statement as the most important sections of the annual report (ranked no. 1). Additionally, users rank the balance sheet as equally important as the income statement and cash flow statement. These results are almost consistent with previous Malaysian studies (Ahmad 1988; Rahman 1999, 2001; and Ho and Wong 2001). The only difference in this paper's findings is with regard to the notes to the financial statements, which are reported in the top three in this study instead of the cash flow statement as in prior studies. Likewise, preparers in Hong Kong rank the notes to the financial statements instead of the cash flow statement in the top three most important sections in annual reports (Ho and Wong 2001). In addition, the cash flow statement is also not found to be one of the three most important sections of the annual report in Iran (Mirshekary and Saudagaran 2005) and Saudi Arabia (Al-Razeen and Karbhari 2007). Surprisingly, these two previous studies find the auditors' report to be listed along the profit and loss account and the balance sheet in the top three sections. 
Ghazali-TheImportanceand UsefulnessofCorporate Annual Reportsin Malaysia

Table 6. Importance of Different Sections of Annual Reports

\begin{tabular}{|c|c|c|c|c|c|c|c|}
\hline & \multicolumn{2}{|c|}{ Total } & \multicolumn{2}{|c|}{ Preparers } & \multicolumn{2}{|c|}{ Users } & \multirow{2}{*}{$\begin{array}{l}\text { Sig. } \\
\text { level }\end{array}$} \\
\hline & Mean & Rank & Mean & Rank & Mean & Rank & \\
\hline Income Statement & 4.62 & 1 & 4.71 & 1 & 4.53 & 1 & .538 \\
\hline Balance Sheet & 4.59 & 3 & 4.65 & 3 & 4.53 & 1 & .683 \\
\hline Cash Flow Statement & 4.62 & 1 & 4.71 & 1 & 4.53 & 1 & .538 \\
\hline $\begin{array}{l}\text { Notes to the financial } \\
\text { statements }\end{array}$ & 4.53 & 4 & 4.65 & 3 & 4.41 & 4 & .393 \\
\hline $\begin{array}{l}\text { Statement of corporate } \\
\text { governance }\end{array}$ & 3.56 & 8 & 3.47 & 10 & 3.65 & 8 & .611 \\
\hline $\begin{array}{l}\text { Statement on internal } \\
\text { control }\end{array}$ & 3.41 & 11 & 3.35 & 11 & 3.47 & 9 & .726 \\
\hline Directors' Report & 3.56 & 8 & 3.76 & 7 & 3.35 & 10 & .246 \\
\hline Auditors' Report & 3.88 & 6 & 3.94 & 6 & 3.82 & 6 & .770 \\
\hline $\begin{array}{l}\text { Five-year financial } \\
\text { highlights/Financial } \\
\text { summary }\end{array}$ & 3.74 & 7 & 3.76 & 7 & 3.71 & 7 & .857 \\
\hline Chairman's Statement & 3.32 & 12 & 3.29 & 12 & 3.35 & 10 & .872 \\
\hline $\begin{array}{l}\text { Directors and senior } \\
\text { management profile }\end{array}$ & 3.44 & 10 & 3.53 & 9 & 3.35 & 10 & .558 \\
\hline Operations Review & 4.09 & 5 & 4.18 & 5 & 4.00 & 5 & .544 \\
\hline
\end{tabular}

* significant at $5 \%$ level; ** significant at $1 \%$ level

( $1=$ not important at all; $5=$ very important $)$

Table 6 shows that almost all items in the annual report are ranked the same by both preparers and users. The computed mean scores of each section indicate that on average, preparers and users view the income statement, cash flow statement, balance sheet, the notes to the financial statement and operations review as important sections (mean scores of more than 4).
The statement of corporate governance, the statement on internal control and the chairman's statement are the three least important sections perceived by preparers. This finding is unexpected given that these items were introduced in 2001 to promote corporate transparency and accountability. Users, on the other hand, regard the directors' report, the chairman's re- 
Gadjah Mada InternationalJournal of Business, January-April 2010, Vol. 12,No. 1

port and directors and senior management profiles as the three least important sections in annual reports, implying that users do not really use these sections of the annual report. The finding regarding the directors' report appears to be consistent with prior studies (Ho and Wong 2001; Mirshekary and Saudagaran 2005; Al-Razeen and Karbhari2007). In comparison to prior Malaysian studies, the finding is consistent with regard to the chairman's statement (Rahman 1999, 2001). These results seem to suggest that the perceptions of users in Malaysia on the lack of importance of the chairman's statement have not changed over the last ten years.

To determine whether there are significant differences in the perceptions of users and preparers on the importance of the different sections in annual reports, t-tests are utilized. The results show that none of the mean scores are statistically significant at either 1 percent or 5 percent level. This suggests that statistically, there are no significant differences in the perceptions of users and preparers on the importance of the different sections of annual reports. ${ }^{9}$

\section{Perceived Usefulness of Information Contained in Annual Reports}

Users and preparers are asked on the usefulness of information contained in the annual report. Table 7 shows that preparers rank helping investors/users compare companies' performance as the most important function of information in annual reports (first) followed by evaluating a company's performance over time (second). Users, on the other hand, rank evaluating a company's performance over time as the most important use of annual reports information followed by making comparisons of companies' performance and informed investment decisions. These findings are consistent with Naser et al. (2003) where the above three criteria are mulled the three most important uses of corporate annual reports in Kuwait.

The computed mean scores show that only one item, which is helping investors and users make comparisons among companies' performance (mean score of 4), is regarded as an important function of annual reports by both preparers and users. The $t$ tests reveal that all mean scores are not statistically

${ }^{9}$ Mann-Whitney tests on these items also show that the differences are not statistically significant. 
Ghazali-TheImportanceand UsefulnessofCorporate Annual Reportsin Malaysia

Table 7. Usefulness of Information in the Annual Reports

\begin{tabular}{|c|c|c|c|c|c|c|c|}
\hline \multirow{3}{*}{$\begin{array}{l}\text { Help investors/users in } \\
\text { making informed invest- } \\
\text { ment decision }\end{array}$} & \multicolumn{2}{|c|}{ Total } & \multicolumn{2}{|c|}{ Preparers } & \multicolumn{2}{|c|}{ Users } & \multirow{2}{*}{$\begin{array}{l}\text { Sig. } \\
\text { level }\end{array}$} \\
\hline & Mean & Rank & Mean & Rank & Mean & Rank & \\
\hline & 3.76 & 3 & 3.53 & 5 & 4.00 & 2 & .207 \\
\hline $\begin{array}{l}\text { Help investors/users to } \\
\text { monitor their investment }\end{array}$ & 3.56 & 4 & 3.65 & 4 & 3.47 & 5 & .600 \\
\hline $\begin{array}{l}\text { Help investors/users to } \\
\text { predict income and } \\
\text { earnings per share }\end{array}$ & 3.47 & 6 & 3.29 & 6 & 3.65 & 4 & .275 \\
\hline $\begin{array}{l}\text { Help investors/users in } \\
\text { assessing liquidity of } \\
\text { the company }\end{array}$ & 3.56 & 4 & 3.76 & 3 & 3.35 & 7 & .273 \\
\hline $\begin{array}{l}\text { Help investors/users to } \\
\text { predict future dividends } \\
\text { of the company }\end{array}$ & 3.29 & 7 & 3.18 & 7 & 3.41 & 6 & .502 \\
\hline $\begin{array}{l}\text { Help investors/users to } \\
\text { evaluate company's } \\
\text { performance over time }\end{array}$ & 3.97 & 2 & 3.82 & 2 & 4.12 & 1 & .289 \\
\hline $\begin{array}{l}\text { Help investors/users to } \\
\text { make comparison between } \\
\text { a company's performance } \\
\text { with other companies' } \\
\text { performance }\end{array}$ & 4.00 & 1 & 4.00 & 1 & 4.00 & 2 & 1.00 \\
\hline
\end{tabular}

$(1=$ not important at all; $5=$ very important $)$

significant at either 1 percent or 5 percent level. This suggests that on average, there is no significant difference in the perceptions of preparers and users on the usefulness of information contained in annual reports.

\section{Corporate Disclosure}

In addition to the importance of annual reports, respondents are also asked about certain aspects of their views on disclosure in annual reports. Table 8 shows that with respect to the adequacy of current disclosure, preparers seem to feel that there should be a slight improvement in the level of disclosure. On the other hand, users are of the view that some improvements in annual report disclosure are necessary. Statistically, the results show that the difference in the opinions between preparers (mean $=2.35)$ and users (mean $=3.06$ ) with respect to the adequacy of current disclosure is significant at 5 percent level. These results corroborate Ho and Wong (2001) 
where users perceive a significantly greater need for improvement than do preparers.

On the question of whether there should be more disclosure in annual reports, the finding is again consistent with Ho and Wong (2001); there is a statistically significant difference between the perception of preparers and that of users. Preparers' responses on average are from moderately agree to more disclosure $($ mean $=2.76)$ whereas users tend to agree more (mean = 3.53). This evidence may imply that users view additional disclosure to be value relevant for their decision-making purposes. The findings may also suggest that there is a gap between what users require and the information provided in annual reports.

The difference in the opinions between preparers and users is not surprising as prior research has reported that the costs and benefits of additional (voluntary) disclosure are not the same for preparers and users (McKinnon 1984, and Gray et al. 1990). Although additional disclosure may help analysts make a better informed decision, the disclosure may involve additional costs of preparation and releasing information to competitors on the part of the preparers.

Respondents are also asked as to whether current disclosure in annual reports is already adequate. The results show that bothusers and preparers are in accord that more disclosure in annual reports would improve corporate transparency and market efficiency. Table 8 shows that the mean score for preparers $(=3.24$; moderately agree) is not significantly different from that for users $(=3.82$; much), although users seem to regard additional disclosure more highly than do preparers.

Table 8. Views on Disclosure in Annual Reports

\begin{tabular}{|c|c|c|c|c|}
\hline & Total & Preparers & Users & Sig. level \\
\hline $\begin{array}{l}\text { +Adequacy of current disclosures } \\
\text { in annual report }\end{array}$ & 3.06 & 2.35 & 3.06 & $.032 *$ \\
\hline $\begin{array}{l}++ \text { Should there be more disclosures } \\
\text { in annual reports }\end{array}$ & 3.15 & 2.76 & 3.53 & $.042 *$ \\
\hline $\begin{array}{l}++ \text { Would more disclosure improve } \\
\text { corporate transparency and market } \\
\text { efficiency }\end{array}$ & 3.53 & 3.24 & 3.82 & .194 \\
\hline \multicolumn{5}{|c|}{$\begin{array}{l}\text { * significant at } 5 \% \text { level } \\
+(1=\text { already very good; } 5=\text { need complete overhaul }) \\
++(1=\text { not at all } ; 5=\text { very much })\end{array}$} \\
\hline
\end{tabular}


Ghazali-TheImportanceand UsefulnessofCorporate Annual Reportsin Malaysia

Table 9. The Influence of Corporate Governance Characteristics on Voluntary Disclosure in Annual Reports

\begin{tabular}{|c|c|c|c|c|}
\hline & Total & Preparers & Users & Sig. level \\
\hline The existence of an audit committee & 3.85 & 4.00 & 3.71 & .326 \\
\hline $\begin{array}{l}\text { No one shareholder owns more than } \\
5 \% \text { voting shares }\end{array}$ & 3.56 & 3.35 & 3.76 & .246 \\
\hline $\begin{array}{l}\text { Non-family members dominating } \\
\text { the board }\end{array}$ & 3.74 & 3.71 & 3.76 & .862 \\
\hline $\begin{array}{l}\text { Separation of the role of chairman } \\
\text { and CEO }\end{array}$ & 3.88 & 3.59 & 4.18 & .100 \\
\hline $\begin{array}{l}\text { Two or more independent non- } \\
\text { executive directors }\end{array}$ & 3.68 & 3.65 & 3.71 & .881 \\
\hline
\end{tabular}

$(1=$ not at all; $5=$ very much $)$

On the question of corporate governance, overall, the mean scores for all items are more than 3.0, meaning that respondents view corporate governance characteristics as factors influencing disclosure. This would suggest that efforts to enhance corporate transparency through corporate governance initiatives have been well accepted by the business industry in Malaysia. On average, preparers view the existence of an audit committee as a factor that could influence corporate voluntary disclosure in annual reports (mean $=4.00)$. The other corporate governance characteristics are not expected to affect voluntary disclosure that much (mean scores of between 3 and 4). Users are of the opinion that the separation of the role of chairman and chief executive officer (CEO) is a factor influencing voluntary disclosure (mean score $=4.18)$.
Additionally, there are no significant differences in the mean scores between preparers and users. This implies that preparers and users are on average of the same view on the extent to which each corporate governance item influences voluntary disclosure in annual reports. However, these findings are inconsistent with Ho and Wong (2001) who report significant differences in the perceptions of preparers and users in Hong Kong. A possible explanation for the difference in findings could be due to the time period of investigation. The present study is carried out in a period where new corporate governance initiatives have been implemented. The finding appears to suggest that the Malaysian business community has started to acknowledge the importance of good governance in ensuring an entity's continued success. 


\section{Summary and Conclusion}

\section{Summary}

This study aims to explore the perceptions of preparers and users on the issue of whether corporate annual reports are useful and an important source of corporate information. Based on the analysis of responses, it could be said that preparers and users in general regard the annual report as one of the most important sources of corporate information as compared to other sources. Analysts, however, regard the visits to companies as the most important source of corporate information. That could partly be attributable to problems with using annual reports, such as the delay in publishing (Mirshekary and Saudagaran 2005) and the lack of information (AbuNassar and Rutherford 1996; Mirshekary and Saudagaran 2005). Through company visits, on the other hand, analysts could build a rapport with company management during their discussion, and this could make it easier for the analysts to obtain more 'timely and relevant' information from the company. Private meetings with company management may be the more effective method of communications to obtain additional corporate information.

As shown in Table 6, users tend to use annual reports to help them evaluate a company's performance over time while preparers feel that annual reports are useful for the comparisons of performance among companies. This could partly be due to the way annual reports are prepared. The regulatory framework governing the preparation of company accounts helps ensure that the annual report is a credible and attested public document. Accordingly, this suggests that the efforts of regulatory bodies in continuously reviewing the standards are not fruitless.

On the issue of whether current disclosure in annual reports is adequate, preparers are of the view that a slight improvement is necessary while users feel that some improvements are required. Preparers and users are also of differing opinions as to whether there should be more disclosure. Preparers tend to agree moderately while users are more agreeable on having more disclosure. This difference is statistically significant at 5 percent level. These findings imply that information needs of users have not been fully provided by the annual report.

\section{Limitations of Study}

This study has examined the perception of only one user-group of annual reports, i.e., investment analysts. Hence, the results may not be generalized to other users of annual reports. Other users such as creditors, government authorities, bankers, institutional investors and academics may have different views on the use and importance of annual reports. For example, government authorities can always request the information it wants directly from a company, and therefore may not find the annual report as the most important source of corporate infor- 
Ghazali-TheImportanceand UsefulnessofCorporate Annual Reportsin Malaysia

mation. Academics may use annual reports for research purposes and rate the annual report as the most important source of corporate information for this purpose if they do not have access to other channels for corporate information.

This research has only employed the questionnaire method to elicit opinions from users and preparers. It is considered appropriate to use mail questionnaires since this method allows respondents to have some time to think through the issues raised in the questionnaire, and give well-thought answers to the questions. However, as reported in Section 4 above, the response rate is less than 30 percent, and the usable replies are only 34 . Hence, the results should be interpreted cautiously.

\section{Suggestions for Future Research}

Future research could perhaps consider expanding the categories of participants to include those excluded from this study. Different users may have different views on the use and importance of annual reports. The views of different users on annual reports could be a basis upon which future revision on accounting standards could focus. Future research could also investigate the information needs of the various groups of users. As shown in Table 8, there are significant differences in the opinions of preparers and users on the disclosure in annual reports. The findings imply that there is an information gap between preparers and users. Perhaps future research could investigate the information requirements of users and whether the information required is currently provided in annual reports.

Apart from administering a postal survey, future research could also conduct face-to-face interviews to gain additional insights into the use and importance of annual reports. A closeended questionnaire may have forced respondents into choosing one of the proposed answers, and although it is possible to include open-ended questions in a survey, it is much easier to express one's feelings during open discussion rather than on a printed questionnaire.

\section{Conclusion}

In conclusion, it may be said that the annual report is an important corporate dossier for preparers and users. It appears that users, such as analysts, refer to the annual reports in making investment decisions. However, the annual report is ranked by analysts as the second important after the visits to companies. This finding could be due to a number of factors, including the timeliness of information and the existence of other channels of corporate communications. Both preparers and users regard the financial components of an annual report (income statement, cash flow statement and balance sheet) as the most important sections, implying that the bottom line in the corporate world is the financial position. It is rather surprising that preparers and 
users do not regard the statement of corporate governance and the statement on internal control as the more important sections in the annual report. Perhaps the mandatory disclosure of these 'standard' statements renders them less relevant for comparison purposes. On the issue of disclosure in annual reports, the difference in opinions indicates that users require much more information whereas preparers are reluctant to disclose more than required possibly due to costs consideration. This raises the question as to what the purposes of annual reports and whose interests they supposed to serve are. It is also interesting to note that respondents in this study opine that corporate governance factors would have some impacts on disclosure in annual reports. Further research is required to gain additional insights into issues relating to corporate annual reports.

\section{References}

Abu-Nassar, M., and B. A. Rutherford. 1996. External users of financial reports in less developed countries: The case of Jordan. British Accounting Review 28: 73 - 87.

Ahmad, S. N. S. 1988. The role of company annual reports for investment analysis in a developing country: The case of Malaysia. Ph.D. Thesis. University of Stirling, Scotland, UK.

Al-Razeen, A., and Y. Karbhari. 2007. An empirical investigation into the importance, use and technicality of Saudi annual corporate information. Advances in International Accounting 20: 55 - 74 .

Anderson, R. H. 1981. The usefulness of accounting and other information disclosed in corporate annual reports to institutional investors in Australia. Accounting and Business Research 11 (44): 259-265.

Baker, H. K., and J. A. Haslem. 1973. Information needs of individual investors. Journal of Accountancy 136(5): 64-69.

Barker, R. G. 1998. The market for information-evidence from finance directors, analysts and fund managers. Accounting and Business Research 29 (1): 3 - 20.

CA. 1965. Companies Act 1965 (Act 125), and Subsidiary Legislation (2002). International LawBook Services, Kuala Lumpur.

Capulong, V., D. Edwards, D. Webb, and J.Zhuang (eds.). 2000. Corporate governance and finance in East Asia. A study of Indonesia, Republic of Korea, Malaysia, Philippines and Thailand: Volume One(A Consolidated Report). A publication prepared under the Asian Development Bank's regional Technical Assistance 5802.

Cerf, A. R. 1961. Corporate Reporting and Investment Decisions. University ofCalifornia, Berkeley, California.

Chandra, G. 1974. A study of the consensus on disclosure among public accountants and security analysts. Accounting Review 49 (4): 733 - 742. 
Ghazali-TheImportanceand UsefulnessofCorporate Annual Reportsin Malaysia

Chandra, G., and M. N. Greenball. 1977. Management reluctance to disclose: An empirical study. Abacus 13 (2): $141-154$.

Chang, L. S., K. S. Most, and C. W. Brain. 1983. Theutility ofannual reports: An international study. Journal of International Business Studies 14 (Spring/Summer): 63 - 84.

Christopher, T., and S. Hassan. 1999. Usefulness of statement of cash flows: Evidence from Malaysian analysts. Asian Review of Accounting 7 (2): 84 - 95.

Claessens, S., S. Djankov, and L. H. P. Lang. 2000. The separation of ownership and control in East Asian corporations. Journal of Financial Economics 58: 81 - 112.

Eccles, R. G., and S. C. Mavrinac. 1995. Improving the corporate disclosureprocess. Sloan Management Review(Summer): 11-25.

Gray, S. J., L. H. Radebaugh, and C. B. Roberts. 1990. International perceptions of cost constraints on voluntary information disclosure: A comparative study of UK and US multinationals. Journal of International Business Studies 21 (4): 597-622.

Hines, R. D. 1982. The usefulness of annual reports: the anomaly between the efficient market hypothesis and shareholder surveys. Accounting and Business Research 12 (48): 296-304.

Ho, S. S. M., and K. S. Wong. 2001. A study of corporate disclosure practice and effectiveness in Hong Kong. Journal of International Financial Management and Accounting 12(1): 75 - 102.

Ho, S. S. M., and K. S. Wong. 2004. Investment analysts' usage and perceived usefulness of corporate annual reports. Corporate Ownership and Control 1 (3): 61 - 71.

Hooks, J., D. Coy, and H. Davey. 2002. The information gap in annual reports. Accounting, Auditing and Accountability Journal 15 (4): 501 - 522.

KLSE. 2001. Listing Requirements of Kuala Lumpur Stock Exchange. KLSE.

MCCG. 2000. Malaysian Code on Corporate Governance. MICG.

McKinnon, S. M. 1984. A cost-benefit study of disclosure requirements for multinational corporations. Journal of Business Finance and Accounting 11 (4): 451 - 468.

Mirshekary, S., and S. Saudagaran. 2005. Perceptions and characteristics of financial statement users in developing countries: Evidence from Iran. Journal of International Accounting, Auditing and Taxation 14 (1): $33-54$.

Naser, K., K. Al-Khatib, and Y. Karbhari. 2002. Empirical evidence on the depth of corporate information disclosure in developing countries: The case of Jordan. International Journal of Commerce and Management 12 (3 \& 4): 122 - 155.

Naser, K., and R. Nuseibeh. 2003. Users' perceptions of corporate reporting: Evidence from Saudi Arabia. The British Accounting Review 35: 129 - 153.

Naser, K., R. Nuseibeh, and A. Al-Hussaini. 2003. Users' perceptions of various aspects of Kuwaiti corporate reporting. Managerial Auditing Journal 18 (6/7): 599-617.

Oppenheim, A. N. 1992. Questionnaire Design, Interviewing and Attitude Measurement. New Edition. Pinter Publishers.

Parker, L. D. 1982. Corporate annual reporting: A mass communication approach. Accounting and Business Research 12 (48): 279-286. 
Gadjah Mada InternationalJournal of Business, January-April 2010,Vol. 12,No. 1

Rahman, A. A. 1999. The use of annual reports by Malaysian financial analysts - A preliminary survey. Akauntan Nasional 11/12: 26-32.

Rahman, A. A. 2001. The use and importance of annual reports byaccountants in the service industry in Malaysia. Asian Review of Accounting 9 (2): 117 - 128.

Rogers, R. K., and J. Grant. 1997. Content analysis of information cited in reports of sellside financial analysts. The Journal of Financial Statement Analysis (Fall): 17 - 30.

Stainbank, L., and C. Peebles. 2006. The usefulness of corporate annual reports in South Africa: perceptions of preparers and users. Meditari Accountancy Research 1 (1): 69 -80 .

Vergoossen, R.G.A. 1993. The use and perceived importance of annual reports by investment analysts in the Netherlands. European Accounting Review (2):219-244. 